\title{
Evaluation of electricity production from alkaline pretreated sludge using two-chamber microbial fuel cell
}

\author{
Benyi Xiao, Fang Yang, Junxin Liu* \\ Research Center for Eco-Environmental Sciences, Chinese Academy of Sciences, Beijing 100085, China
}

\section{H I G H L I G H T S}

- The electricity output of alkaline pretreated sludge was $46.80-55.88 \mathrm{~mW} / \mathrm{m}^{2}$.

- The anode resistance was the main internal resistances (75\%) at the stable stage.

- The methane production did not obviously affect the production of electricity.

- Two possible methods for enhancing the electricity production were found.

\section{A R T I C L E I N F O}

\section{Article history:}

Received 20 December 2012

Received in revised form 14 March 2013

Accepted 16 March 2013

Available online 25 March 2013

\section{Keywords:}

Alkaline pretreatment

Electricity production

Evaluation

Sewage sludge

Two-chamber microbial fuel cell

\begin{abstract}
A B S T R A C T
Electricity production from alkaline pretreated sludge was evaluated using a two-chamber microbial fuel cell (MFC). The electricity production was found to be stable over a long period of time (approximately 17 d) with voltage outputs and power densities of $0.47-0.52 \mathrm{~V}$ and $46.80-55.88 \mathrm{~mW} / \mathrm{m}^{2}$, respectively. The anode resistance was the main internal resistance (73.2\%) of MFC in the stable stage. Most soluble organic matters (proteins and carbohydrates) in the anode chamber were first degraded and converted into volatile fatty acids $(0-15 d)$, which were then degraded and converted into electricity and methane (15-29 d). The insoluble organics were solubilized thereby decreasing the sludge concentration and reducing the sludge mass. Methane was produced in the anode chamber owing to the growth of methanogens, which did not obviously affect the electricity production. The change in humic-like substances displayed a positive correlation with the electricity production of the MFC. Microbial analysis showed that methanogens and electricity-producing bacteria co-existed mostly on the surface as well as inside the anode. Decreasing the anode resistance and increasing the anode utilization could enhance the electricity production.
\end{abstract}

Crown Copyright $@ 2013$ Published by Elsevier B.V. All rights reserved.

\section{Introduction}

Sewage sludge is the main by-product from biological wastewater treatment requiring treatment and disposal. Increased amounts of wastewater requiring treatment have led to an increase in the generation of sewage sludge. For example, excess sludge production in China in 2010 was approximately $2.2 \times 10^{7} \mathrm{t}$ (water content $80 \%$ ) [1]. The sludge needs to be treated further and disposed of to minimize its environmental impact. Although the sludge amounts to only a few percent by volume of processed wastewater, its handling accounts for $25-65 \%$ of the total plant operation cost $[2,3]$ and its disposal has become problematic for many wastewater treatment plants. However, the sewage sludge contains large amounts of organic matter, mainly protein and carbohydrate [4-6]. Wilson and Novak [5] found the total protein in primary

\footnotetext{
* Corresponding author. Tel.: +86 10 62849133; fax: +86 1062849133 .

E-mail address: jxliu@rcees.ac.cn (J. Liu).
}

and secondary wastewater sludge to be $13,400 \pm 1700 \mathrm{mg} / \mathrm{L}$ and $31,200 \pm 1300 \mathrm{mg} / \mathrm{L}$, respectively, and Wang et al. [6] found the quantities of protein and carbohydrate in sludge to be $12,036 \mathrm{mg} / \mathrm{L}$ and $2109 \mathrm{mg} / \mathrm{L}$, respectively. The organic matter in sludge could be used to produce useful materials and/or energy (such as hydrogen, methane, and electricity), and much research has been conducted, especially on the release of organics from microbial cells of sludge $[4,7-9]$. It therefore seems logical to recover value from the treatment and disposal of sludge.

The microbial fuel cell (MFC) is a bio-electrochemical system that converts chemical energy to electrical energy in the dissolved biomass by the catalytic reaction of microorganisms [10,11]. MFCs can produce electricity from a variety of materials including organic wastes [12], such as brewery wastewater [13], starch processing wastewater [14], paper recycling wastewater [15], and sludge $[9,16-20]$. The electricity production from sewage sludge is lower. Dentel et al. [16] first reported electricity production from sludge using sediment MFC and obtained a maximum electrical current of roughly $0.065 \mathrm{~mA}$ and a maximum voltage of $0.517 \mathrm{~V}$. Since 
then, much research has been published on this topic in the academic community. Jiang et al. [17] obtained a maximum power density of $8.5 \mathrm{~W} / \mathrm{m}^{3}$ from sludge using a two-chamber MFC and Liu et al. [18] obtained a maximum voltage of $440.7 \mathrm{mV}$ and a maximum power density of $220.7 \mathrm{~mW} / \mathrm{m}^{2}$ by using a single-chamber, membrane-less and floating-cathode MFC.

However, to date, the maximum power density obtained from sewage sludge has increased from tens to hundreds of megawatts per square meter, which is far lower than that from simple organics or organic wastewater. Some methods have been used to improve the electricity production from sludge. These methods include alkaline pretreatment $[19,21,22]$, thermal pretreatment [19], ultrasound pretreatment [21], enzyme addition [23], biocathode [19,20], aerobic digestion [19], and so on. Our previous study [19] showed that electricity production from sewage sludge could be increased by thermal and especially alkaline pretreatment, and the voltage outputs and power densities were increased from $0.28-0.31 \mathrm{~V}$ and $17.3-21.2 \mathrm{~mW} / \mathrm{m}^{2}$ to $0.41-0.43 \mathrm{~V}$ and $36.8-40.1 \mathrm{~mW} / \mathrm{m}^{2}$, respectively. Yang et al. [23] studied the effect of additional enzymes on the electricity production of sludge and found that both neutral protease and $\alpha$-amylase could enhance electricity production using sludge with an electricity density enhancement to 507 and $700 \mathrm{~mW} / \mathrm{m}^{2}$, respectively, when the enzyme concentration was $10 \mathrm{mg} / \mathrm{gTS}$.

Alkaline pretreatment could disintegrate the microbial cell of sludge, solubilize the sludge organic matters and increase the microbial availability of these matters $[24,25]$. Alkaline pretreatment has therefore been studied by several researchers [19-22] and is believed to be a potential method for enhancing electricity production. Jiang et al. [21] found the power output increased from 10.3 to $12.5 \mathrm{~W} / \mathrm{m}^{3}$ by using combined ultrasonic and alkaline sludge pretreatment. Wang et al. [22] found that alkaline pretreatment could enhance the electricity production from sludge in the twochamber MFC and the maximal power density could be enhanced 4.2 times when the sludge $\mathrm{pH}$ was adjusted to 9.0 for $24 \mathrm{~h}$.

To date, the microscopic changes and mechanism of electricity production using alkaline pretreated sludge have not been studied. The factors affecting the electricity production from alkaline pretreated sludge are not clear. Therefore, methods that could further enhance or be feasible for electricity production from alkaline pretreated sludge are also not clear. The objective of this study was to evaluate the electricity-producing process of alkaline pretreated sludge in a two chamber MFC to assess feasible methods for enhancing electricity production. This was done by investigating microscopic changes of sludge in the electricity production process and by studying the electricity-producing mechanism.

\section{Materials and methods}

\subsection{Sewage sludge and alkaline pretreatment}

Sewage sludge was obtained from the secondary sedimentation tank of a municipal wastewater treatment plant in Beijing, China, which uses the activated sludge process and handles 400,000t wastewater daily. The anaerobic sludge, which was used as the inoculum of the anode chamber, was obtained from the anaerobic sludge digester of another municipal wastewater treatment plant in Beijing, China. The collected sludge samples were first filtered using a 40-mesh sieve to remove the larger particles and allowed to settle by gravity for approximately $1 \mathrm{~h}$. The sediments were stored at $4{ }^{\circ} \mathrm{C}$ before use. The sewage sludge was adjusted to the appropriate concentration and then alkaline pretreated as discussed previously [19]. Some characteristics of the sewage sludge, alkaline pretreated sludge, anaerobic sludge and sludge mixture in the anode chamber are summarized in Table 1.

\subsection{Electricity production from alkaline pretreated sludge}

The MFC was constructed as described previously using a $5 \mathrm{~cm}^{2}$ proton exchange membrane (Nafion117) [19]. The $4 \mathrm{~cm} \times 6 \mathrm{~cm} \times 0.5 \mathrm{~cm}$ anode and $4 \mathrm{~cm} \times 6 \mathrm{~cm} \times 0.1 \mathrm{~cm}$ cathode were made of carbon felt (Sanye Carbon Co., China) and carbon paper without wet proofing (Toray Co., Japan), respectively, and were located $14 \mathrm{~cm}$ apart. Copper wire was used to connect the external circuit with a $1000 \Omega$ fixed external resistance.

Alkaline pretreated sludge $(350 \mathrm{ml})$ and anaerobic sludge $(50 \mathrm{ml})$ were added to the MFC anode chamber and sewage sludge was added $(315 \mathrm{ml})$ to the cathode chamber. Trace element solution (5 $\mathrm{ml}$ ) [26] was also added to each chamber. The $\mathrm{pH}$ of the sludge in the two chambers was adjusted to $7.0 \pm 0.1$ with $6 \mathrm{M} \mathrm{NaOH}$ or $6 \mathrm{M} \mathrm{HCl}$. The dissolved oxygen content in the cathode chamber was maintained at approximately $5.0 \mathrm{mg} / \mathrm{L}$ by aeration to ensure the presence of sufficient dissolved oxygen in the mixed liquid [27] The mixed sludge in the anode chamber was agitated by magnetic stirring. Deionized water was supplied periodically to maintain the volume of the mixed liquid in the cathode chamber. The MFC was operated at room temperature $\left(18-28^{\circ} \mathrm{C}\right)$ and the tests were carried out in triplicate with all results being mean values.

\subsection{Analysis methods}

The MFC voltages were recorded using a precision digitalmultimeter and a data acquisition system (Ruibohua Co., China) connected to a computer. The polarization curves were detected by verifying external resistances from $50,000 \Omega$ to $30 \Omega$ with an interval of 2 min to gain stable voltages when the MFC performance was stable. The open circuit voltage, internal resistance and maximal power density were obtained from analysis of the polarization curves [28].

The soluble chemical oxygen demand (SCOD) and total chemical oxygen demand (TCOD) of the sludge samples were quantified using a HACH COD measurement system and kit (HACH Co., USA). Sludge samples were filtered using $0.45 \mu \mathrm{m}$ membranes before determining their SCOD. The $\mathrm{pH}$ of the sludge was measured with a pH meter (PHS-3C, China). The sludge concentrations (total suspended solids [TSS] and volatile suspended solids [VSS]) were measured according to standard methods [29]. Total proteins of sludge were measured Kjeldahl method [29], soluble proteins by Lowry's method using bovine serum albumin as standard solution [30], and carbohydrates (total and soluble ones) by the phenol-sulfuric acid method using glucose as standard solution [31]. The volatile fatty acids (VFAs) concentrations in the liquid phase were analyzed using a gas chromatograph (Agilent 6890, USA) equipped with a flame ionization detector (FID) and a $30 \mathrm{~m}$ capillary column (FFAP, Agilent, USA). The three-dimensional excitation emission matrix fluorescences for the dissolved organic fractions of sludge were measured by fluorescence spectrometer (Cary Eclipse, USA).

Biogas production in the anode chamber was measured periodically by displacement of saturated aqueous $\mathrm{NaCl}$ in a graduated cylinder [32]. The biogas in the reactor headspace was sampled with a $1 \mathrm{ml}$ gas-tight syringe. Methane $\left(\mathrm{CH}_{4}\right)$ production was calculated from the measurement of methane content and the total volume of biogas produced. The methane content in the biogas was analyzed by another gas chromatograph (Agilent 6890, USA) equipped with a FID and a $30 \mathrm{~m}$ capillary column (HP-5, Agilent, USA). Nitrogen was used as the carrier gas with a flow rate of $30 \mathrm{ml} / \mathrm{min}$.

Visualization of the microorganisms and their distribution on the MFC anode was conducted by fluorescence in situ hybridization (FISH) and scanning electron microscopy (SEM). The sludge was sampled at the anode surface at the end of the test for FISH and SEM analyses, at a 0.125 and $0.250 \mathrm{~cm}$ depth, respectively. Sludge 
Table 1

Sludge sample characteristics.

\begin{tabular}{|c|c|c|c|c|c|}
\hline Item & $\mathrm{pH}$ & TCOD (mg/L) & $\mathrm{SCOD}(\mathrm{mg} / \mathrm{L})$ & TSS $(\mathrm{g} / \mathrm{L})$ & VSS (g/L) \\
\hline Raw sludge & $6.9( \pm 0.1)$ & $11,380( \pm 100)$ & $24.7( \pm 20)$ & $15.67( \pm 0.27)$ & $10.50( \pm 0.19)$ \\
\hline Alkaline pretreated sludge & $12.3( \pm 0.1)$ & $10,560( \pm 110)$ & $3190( \pm 20)$ & $11.45( \pm 0.18)$ & $7.38( \pm 0.25)$ \\
\hline Anaerobic sludge & $7.4( \pm 0.1)$ & $4670( \pm 110)$ & $930( \pm 30)$ & $6.57( \pm 0.27)$ & $3.81( \pm 0.22)$ \\
\hline Sludge mixture in the anode chamber & $7.0( \pm 0.1)$ & $9640( \pm 120)$ & $2870( \pm 30)$ & $10.83( \pm 0.34)$ & $6.72( \pm 0.26)$ \\
\hline
\end{tabular}

Table 2

Oligonucleotide probes used for fluorescence in situ hybridization.

\begin{tabular}{|c|c|c|c|c|c|}
\hline No & Probes & Base sequence (from $5^{\prime}$ to $3^{\prime}$ ) & Modified fluorescein & $\mathrm{HT}^{\mathrm{a}}\left({ }^{\circ} \mathrm{C}\right)$ & $\mathrm{Ht}^{\mathrm{a}}(\mathrm{h})$ \\
\hline 1 & UNIV1392 & ACG GGC GGT GTG TAC & Texas Red & 42 & 2 \\
\hline 2 & MPB1 & CAT GCA CCA CCT CTC AGC & FITC & 46 & 2 \\
\hline 3 & MEB859 & GGA CTT AAC AGC TTC CCT & FITC & 46 & 3 \\
\hline 4 & MSSH859 & CTC ACC CAT ACC TCA CTC GGG & FITC & 46 & 3 \\
\hline 5 & SRB385 & CGG CGT CGC TGC GTC AGG & Су3 & 46 & 2 \\
\hline 6 & SRB687 & TAC GGA TTT CAC TCCT & Су3 & 46 & 2 \\
\hline
\end{tabular}

a HT, hybridization temperature; Ht, hybridization time.
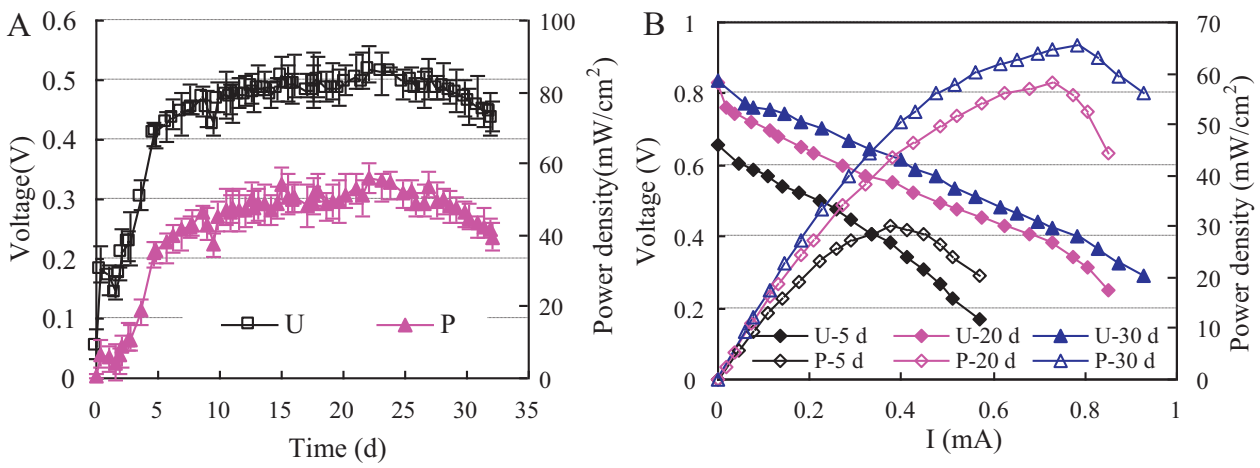

Fig. 1. Electricity production and MFC polarization curves.

sample fixation, sectioning and FISH were performed according to the protocol described previously [33]. Table 2 lists the probe, base sequences, number of bases, modified fluorescein and FISH conditions. MPB1, MEB859 and MSSH859 were the specific probes for the methanogens, Methanobacterium and Methanosarcina, respectively. SRB385 and SRB687 were specific probes for electricity productionrelated sulfate-reducing bacteria [34]. UNIV1392 was the universal probe used for bacteria and archaea as the positive FISH control. Sludge samples were analyzed using a SEM (S-3000N, Hitachi Co., Japan) and the sludge sample preparation method as used by Li [35].

\section{Results and discussion}

\subsection{Electricity production from alkaline pretreated sludge}

Electricity production from the alkaline pretreated sludge in the two-chamber MFC was determined and the results are summarized in Fig. 1A. The electricity production process can be divided into four stages: the initiation, incremental, stable and decreasing stage. The initiation stage occurred from 0 to $3.5 \mathrm{~d}$, during which the electricity-producing bacteria in the anode chamber adjusted and acclimatized to the new conditions and the MFC voltage was increased from 0.05 to $0.23 \mathrm{~V}$. The incremental stage occurred from 3.5 to $10 \mathrm{~d}$, during which the acclimatized microorganisms grew and proliferated and the MFC voltage was increased to $0.47 \mathrm{~V}$. The stable stage occurred from 10 to $27 \mathrm{~d}$, during which the MFC voltage fluctuated from 0.47 to $0.52 \mathrm{~V}$. The power density of the MFC in the stable stage was calculated and ranged from 46.80 to $55.88 \mathrm{~mW} / \mathrm{m}^{2}$ (Fig. 1A). The decreasing stage occurred after the stable stage (after
$27 \mathrm{~d}$ ) and the MFC voltage decreased to $0.435 \mathrm{~V}$ at the end of the test (32 d).

The polarization curves of the MFC were determined in the electricity-producing process $(5,20$ and $30 \mathrm{~d})$, and the results are summarized in Fig. 1B. Three parameters of the MFC in the electricity-producing process are summarized in Table 3. The open circuit voltage and maximal power density increased with the running of the MFC while the internal resistance decreased. The results are similar to our previous study [19]. Compared with the electricity production from simple organics and organic wastewater, the internal resistance of the MFC in this study was higher. For example, Tang et al. [36] obtained a $263 \Omega$ internal resistance using acetate, and Wen et al. [37] obtained a $19 \Omega$ internal resistance using synthetic penicillin wastewater. The higher internal resistance may be one of the reasons for the lower electricity production (power density) from alkaline pretreated sludge. The make-up of the MFC internal resistance during the stable stage ( $20 \mathrm{~d}$ ) was analyzed by electrochemical impedance spectroscopy (data not shown), and the results suggest a division into three parts: anode $(449.2 \Omega$ ), membrane $(84.6 \Omega)$ and cathode $(80.0 \Omega)$ resistances. Since the anode resistances include the transfer of electrons and protons in the anode chamber and the sewage sludge (which contains large amounts of insoluble matter) would obstruct their transfer, it is

Table 3

Three parameters of MFC in the electricity-producing process.

\begin{tabular}{lccc}
\hline Operation time $(\mathrm{d})$ & 5 & 20 & 30 \\
\hline Open circuit voltage $(\mathrm{V})$ & 0.659 & 0.829 & 0.836 \\
Internal resistance $(\Omega)$ & 734.3 & 613.8 & 554.7 \\
Maximal power density $\left(\mathrm{mW} / \mathrm{m}^{2}\right)$ & 29.97 & 58.00 & 65.49
\end{tabular}




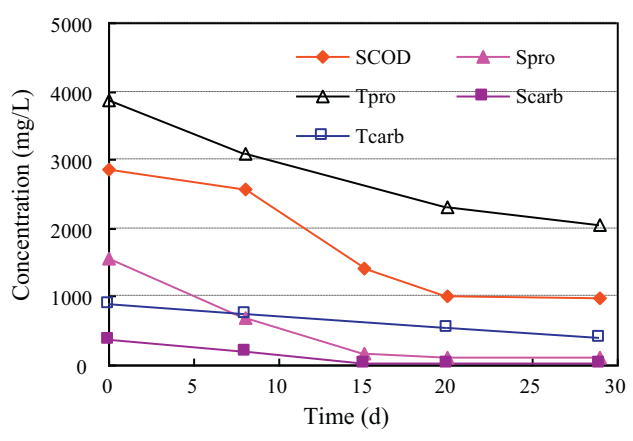

Fig. 2. Changes in soluble and insoluble organic matter in the anode chamber.

logical that the anode resistances are the main component of the internal resistance (approximately 73.2\%). Therefore, to further increase electricity production from alkaline pretreated sludge, the transfer of electrons and protons should be improved.

\subsection{Changes in sludge in the anode chamber}

Proteins and carbohydrates are the main organic components of the sewage and alkaline pretreated sludge [4-7]. In the electricity production process of alkaline pretreated sludge, the two components would be hydrolyzed and their concentrations would decrease (Fig. 2). Most of the soluble proteins $(\approx 56.2 \%)$ and carbohydrates $(\approx 49.3 \%$ ) were degraded in 0 -8 days and their concentrations decreased from $1570.12 \mathrm{mg} / \mathrm{L}$ (soluble proteins) and $373.69 \mathrm{mg} / \mathrm{L}$ (soluble carbohydrates) to 687.14 and $189.46 \mathrm{mg} / \mathrm{L}$, respectively. During the last $14 \mathrm{~d}$, the change in soluble proteins and carbohydrates concentration was minor. Unlike the soluble proteins and carbohydrates, most of the SCOD $(\approx 40.3 \%)$ was removed in $8-15$ days and decreased from 2560 to $1402 \mathrm{mg} / \mathrm{L}$. This may be because the soluble proteins and carbohydrates were converted into soluble organic acids (other components of SCOD) in the first stage and these organic acids were degraded in the second stage. Fig. 2 also summarizes the changes in total proteins and carbohydrates in the test. Unlike the observations made for the soluble species, the overall decrease of total proteins and carbohydrates was almost uniform and approximately $47.0 \%$ (from 3886.08 to $2058.04 \mathrm{mg} / \mathrm{L}$ ) and $54.0 \%$ (from 902.66 to $415.21 \mathrm{mg} / \mathrm{L}$ ), respectively. The result suggests that the insoluble organics (proteins and carbohydrates) were converted continuously into soluble organics in the electricity-producing process in the anode chamber. In the anaerobic digestion or biological hydrogen production of pretreated sludge, similar changes in organic concentrations (proteins and carbohydrates) were observed [4].

The soluble proteins and carbohydrates would be hydrolyzed and eventually converted into VFAs by anaerobic bacteria in the anode chamber, thereby resulting in changes in VFAs concentration (Fig. 3). The VFAs concentration increased in the first two stages (0-15 d) and decreased in the last two stages (15-29 d). Changes in acetic acid, propionic acid and butyric acid concentrations were similar to those of the total VFAs concentration. Acetic acid was the main component of the VFAs at $8 \mathrm{~d}$ and butyric acid (including butyric and isobutyric acid) was the main one after $8 \mathrm{~d}$. The changes in VFAs, soluble proteins, soluble carbohydrates and SCOD were not similar, as the SCOD included other components besides VFAs, soluble proteins and soluble carbohydrates. Changes in VFAs would result in $\mathrm{pH}$ changes (Fig. 3) as high VFAs results reduce $\mathrm{pH}$.

Three-dimensional fluorescence spectra were used widely to study proteins conformational changes $[38,39]$, proteins denaturation and proteins stability and the soluble organic matter in alkaline pretreatment is mostly proteins. So, the changes in soluble protein-like substances and others in sludge organic matter in

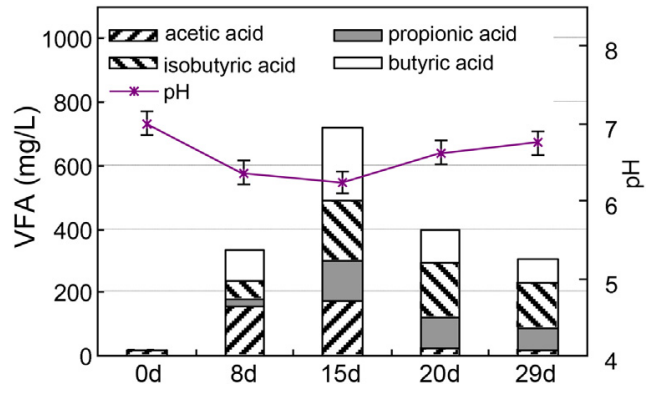

Fig. 3. Changes in VFAs concentration and anode chamber $\mathrm{pH}$.

the anode chamber were analyzed by three-dimensional fluorescence spectra with results summarized in Fig. 4. Compared with a literature study [38], it was found that the tyrosine-like proteins $\left(\lambda_{\mathrm{Ex}} / \lambda_{\mathrm{Em}}=270-290 / 280-320 \mathrm{~nm}\right)$ were present in the four samples with the highest concentration appearing at $8 \mathrm{~d}$. Changes in the tyrosine-like proteins were dissimilar to those of the soluble proteins, which may be because the soluble proteins contain many other proteins with the exception of tyrosine-like proteins. In other words, the results of three-dimensional fluorescence spectra could not be used to characterize the change in total soluble proteins. The concentration of humic-like substances (such as humic acid) $\left(\lambda_{\mathrm{Ex}} / \lambda_{\mathrm{Em}}=310-360 / 350-450 \mathrm{~nm}\right)$ increased over $0-8$ days, was stable over 8-20 days and decreased slightly over 20-29 days. Comparing the changes in three-dimensional fluorescence spectra and electricity production, it could be found that the change in humic-like substances showed a positive correlation with the electricity production of the MFC. The results for the humic-like substances are similar to those of Thygesen et al. [40] and Huang and Angelidaki [41], who found that humic acid could enhance the electricity production of MFC because it could act as mediator.

The conversion of insoluble organics resulted in a decrease in sludge concentration in the MFC anode chamber by approximately $18.58 \%$ TSS (from 10.83 to $8.82 \mathrm{~g} / \mathrm{L}$ ) and $19.49 \%$ VSS (from 6.72 to $5.41 \mathrm{~g} / \mathrm{L}$ ) over $0-15$ days and approximately $11.82 \%$ TSS (from 8.82 to $7.54 \mathrm{~g} / \mathrm{L}$ ) and $13.23 \%$ VSS (from 4.97 to $4.52 \mathrm{~g} / \mathrm{L}$ ) over $15-29$ days. The result suggests that using sludge as fuel could produce electricity and reduce sludge mass simultaneously. The reason for the decrease in sludge concentration is the same as for the conventional anaerobic sludge digestion since the anode chamber is under anaerobic conditions.

Changes in sludge characteristics, including SCOD, soluble proteins and carbohydrates, total proteins and carbohydrate, VFAs, pH, soluble organic matter and sludge concentration were compared with the production of electricity. The change in humic-like substances correlated with electricity production. This is feasible since it has been proven that humic acid could enhance electron transfer [40]. Besides the change in humic-like substances, changes in other parameters were correlated insignificantly with electricity production owing to other organic-converting processes (such as methanation) that exist in the anode chamber.

\subsection{Methane production in the anode chamber}

The anode chamber of the MFC operated under anaerobic conditions and methanogens were important microorganisms in the anaerobic sludge used as inoculum in the anode chamber. So, methane should be produced in the anode chamber in the electricity production process. Methane production was detected in the anode chamber with results summarized in Fig. 5. Methane production over 0-11 days was slow, with a cumulative production of only $20.3 \mathrm{ml}$. However, after 11 days the methane production rates increased, and its total production reached $113.5 \mathrm{ml}$ at the 

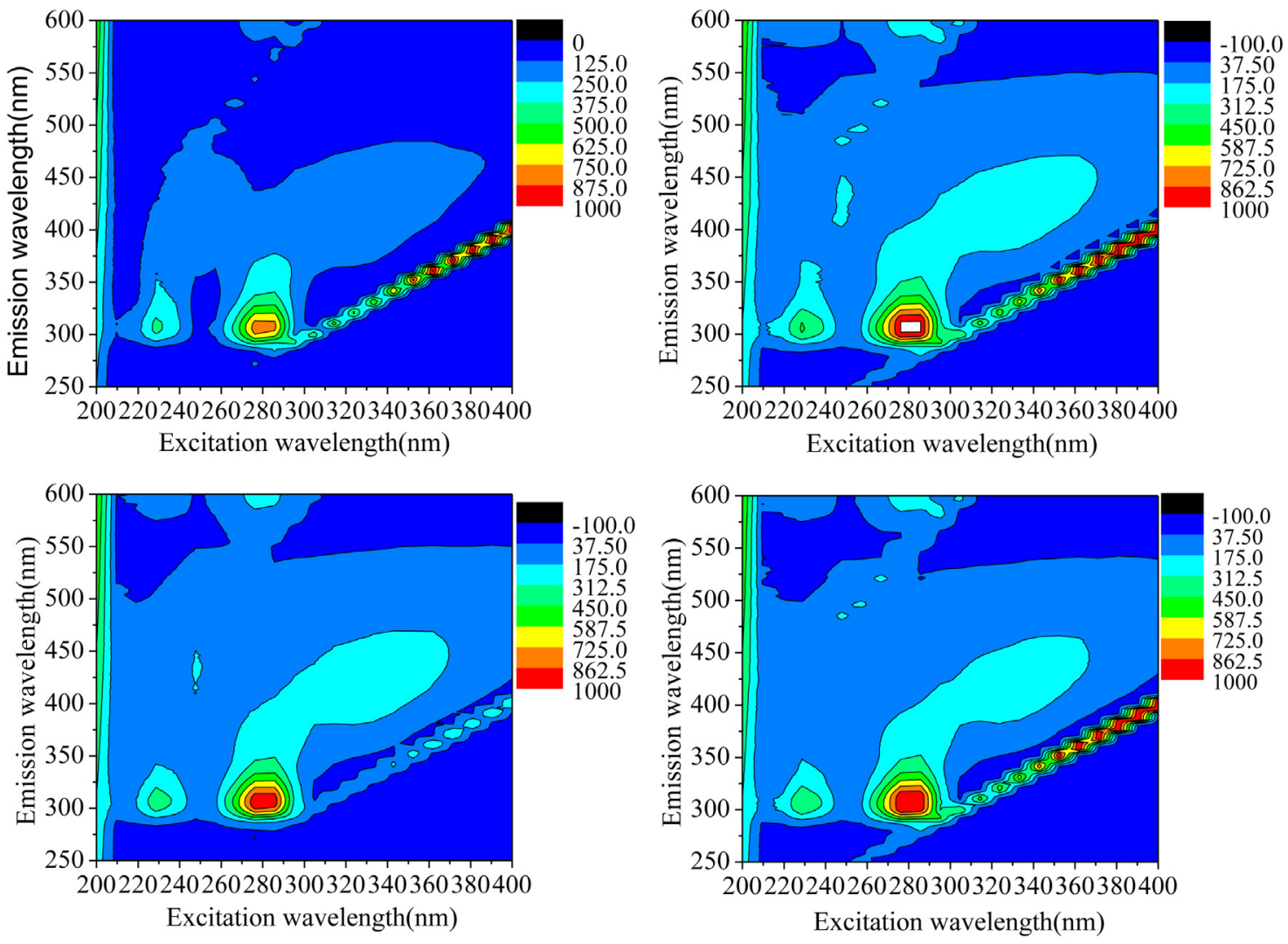

Fig. 4. Fluorescence excitation emission matrices for dissolved fractions of sludge in the anode chamber.

end of the test ( $29 \mathrm{~d})$. The methane producing rate was calculated and the results were also summarized in Fig. 5. It can be seen that the methane producing rate were increased in the stage of $0-15 \mathrm{~d}$ and decreased in the later stage (after $15 \mathrm{~d}$ ). Both of the production of electricity and methane were consistent and increased in the stage of $0-15 \mathrm{~d}$ (Figs. 1 and 5). However, after $15 \mathrm{~d}$, they were different: the former was increased until $25 \mathrm{~d}$ while the latter was decreased. The results suggested that there was no obvious correlation between the electricity producing process of alkaline pretreated sludge and methane producing ones. The result is not consistent with previous studies [42,43]. Chae et al. [42] suggested that methanogens compete actively with exoelectrogens (electricity-producing bacteria) for their substrate in the anode chamber, causing a significant decrease in the performance of MFCs. The reason for this phenomenon may be that the sludge organics were plentiful and were converted gradually from insoluble to soluble organics and methanogens and electricity-producing

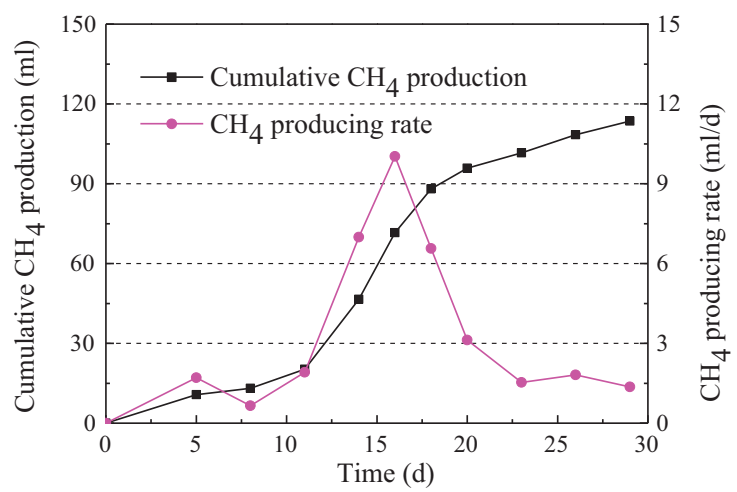

Fig. 5. Production of methane in the anode chamber. bacteria in the anode chamber were not enough to consume the soluble organics in the test. Since both methane and electricity are energy and the two processes could reduce sludge, to recover more energy from the sludge, the two processes should be promoted.

\subsection{Microbial analysis}

To analyze the relationship between the electricity-producing bacteria and methanogens in the anode chamber, electricityproducing bacteria, Methanobacterium and Methanosaeta were selected and their spatial distribution in the anode were analyzed by FISH according to established protocols [33]. The resultant hybridized images are shown in Fig. 6. The results suggest that there were microorganisms on the anode surface and anode interior ( 0.125 and $0.25 \mathrm{~cm}$ deep) and the microorganisms on the surface were more abundant than those interior to the anode. This may be ascribed to the organic substance concentration difference between the outer and inner zones of the anode. The SEM result (Fig. 7) also suggested that the microorganisms on the anode surface were more abundant than those at $0.25 \mathrm{~cm}$ depth. Furthermore, by comparing the microorganism fraction on the surface and the interior of the anode, it was found that the methanogens were richer than the electricity-producing bacteria. This may be because the sample was obtained at the end of the test and the methanogen concentration in the anode chamber had increased substantially with increase in methane production. Additionally, most of the bacteria on the anode surface were bacillus and cocci (Fig. 7).

Both the FISH and SEM results suggest that the microorganisms (including the electricity-producing bacteria and methanogens) were most prevalent on the anode surface and those interior to the anode were few. The results showed that the anode was not utilized effectively. Thus, the electricity-producing bacteria inside the anode could be increased to enhance the anode utilization 


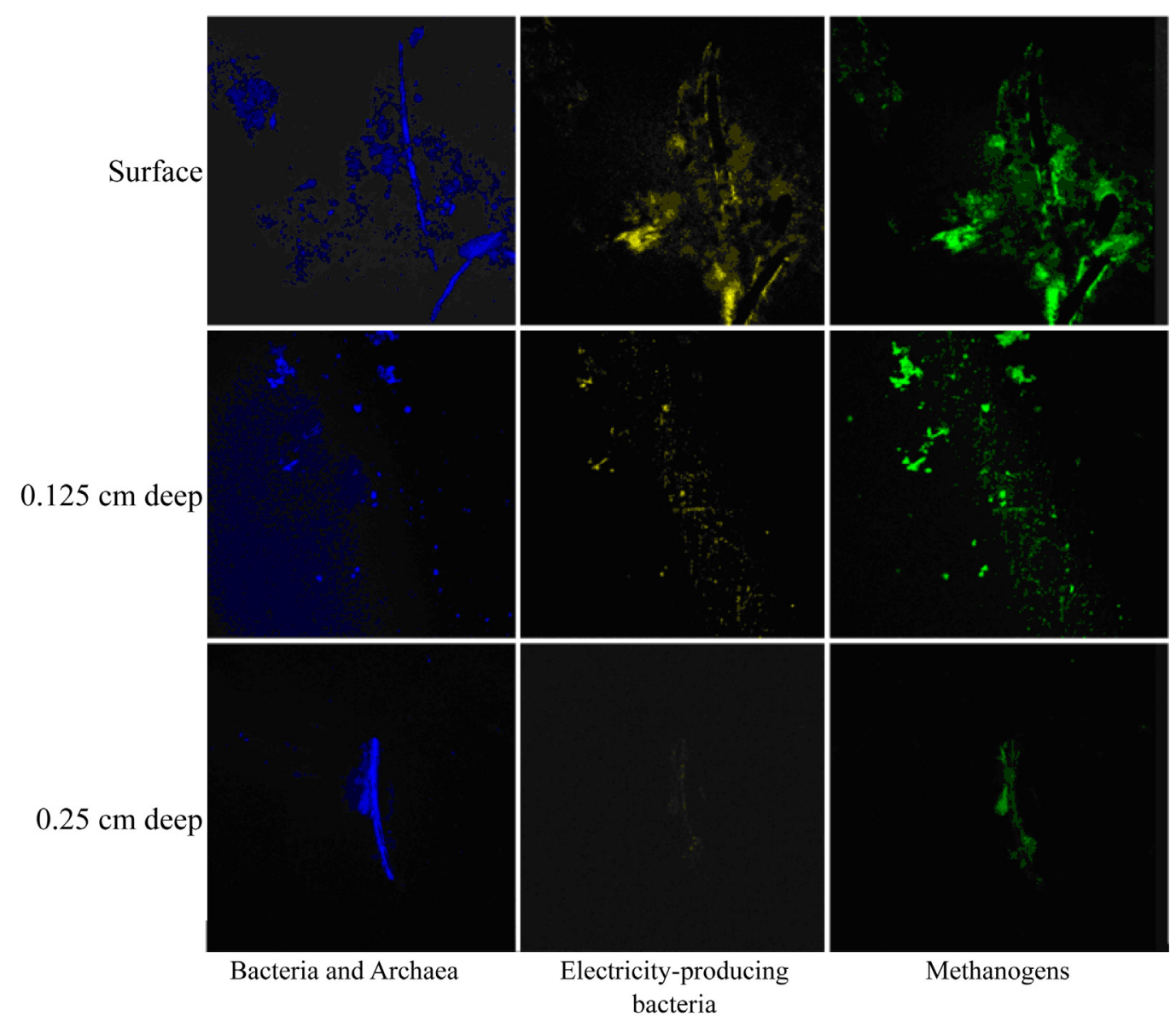

Fig. 6. Fluorescence in situ hybridization images of sludge samples on/in the anode.
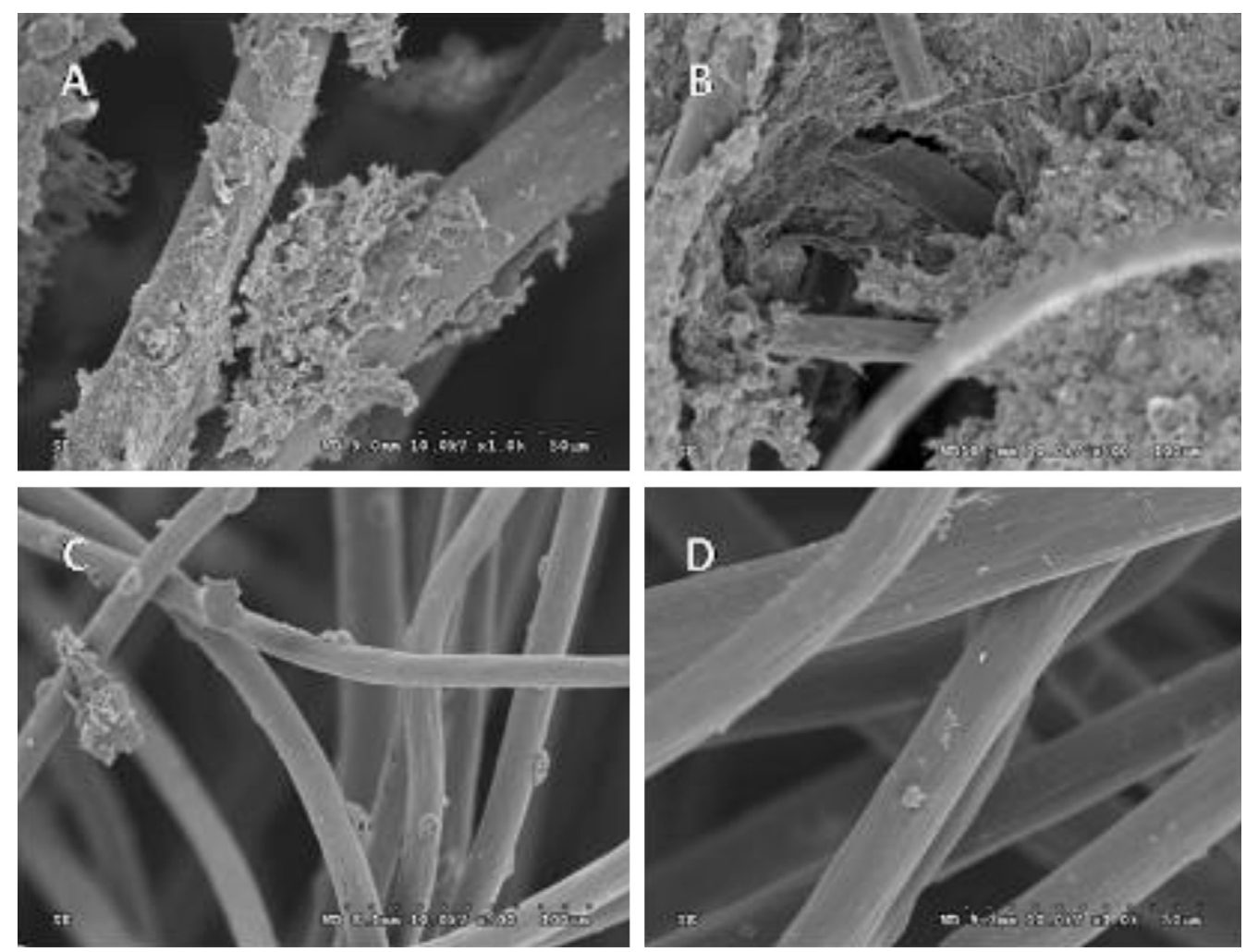

Fig. 7. SEM micrographs of microorganism distribution on the anode. 
rate and improve the electricity production of alkaline pretreated sludge.

\section{Conclusions}

The electricity production of alkaline pretreated sludge was studied using a two-chamber MFC. Stable outputs were $0.47-0.52 \mathrm{~V}$ and $46.80-55.88 \mathrm{~mW} / \mathrm{m}^{2}$ with anode $(272.8 \Omega)$, membrane $(51.4 \Omega)$ and cathode $(48.6 \Omega)$ resistances. Most soluble organics in the anode chamber were converted into VFAs (0-15 d), and these were then converted into electricity and methane (15-29 d). Methane was produced in anode chamber without obviously affecting electricity production. Methanogens and electricity-producing bacteria occurred inside and mostly on the anode surface. The change in humic-like substances exhibited a positive correlation with the electricity production of the MFC. Decreasing the anode resistance and increasing the anodic electricity-producing bacteria could improve the electricity production.

\section{Acknowledgments}

The authors are grateful to the National Natural Science Foundation of China (no. 51008295) and the State Key Laboratory of Environmental Aquatic Chemistry (no. 11Y01ESPCR) for their financial support.

\section{References}

[1] China Statistics Bureau, China Statistical Bulletin, 2011

[2] Y. Wei, R.T. Van Houten, A.R. Borger, D.H. Eikelboom, Y. Fan, Minimization of excess sludge production for biological wastewater treatment, Water Res. 37 (2003) 4453-4467.

[3] Y. Liu, Chemically reduced excess sludge production in the activated sludge process, Chemosphere 50 (2003) 1-7.

[4] M. Cai, J. Liu, Y. Wei, Enhanced biohydrogen production from sewage sludge with alkaline pretreatment, Environ. Sci. Technol. 38 (11) (2004) 3195-3202.

[5] C.A. Wilson, J.T. Novak, Hydrolysis of macromolecular components of primary and secondary wastewater sludge by thermal hydrolytic pretreatment, Water Res. 43 (2009) 4489-4498.

[6] F. Wang, S. Lu, M. Ji, Components of released liquid from ultrasonic waste activated sludge disintegration, Ultrason. Sonochem. 13 (2006) 334-338.

[7] M. Carballa, C. Duran, A. Hospido, Should we pretreat solid waste prior to anaerobic digestion? An assessment of its environmental cost, Environ. Sci. Technol. 45 (2011) 10306-10314.

[8] L. Appels, J. Baeyens, J. Degrève, R. Dewil, Principles and potential of the anaerobic digestion of waste-activated sludge, Prog. Energy Combust. Sci. 34 (2008) 755-781.

[9] Y.Zhang, L.G. Olias, P. Kongjan, I. Angelidaki, Submersible microbial fuel cell for electricity production from sewage sludge, Water Sci. Technol. 64 (1) (2011) 50-55.

[10] B.E. Logan, J.M. Regan, Microbial fuel cells-challenges and applications, Environ. Sci. Technol. 40 (2006) 5172-5180.

[11] B.E. Logan, B. Hamelers, R. Rozendal, U. Schröder, J. Keller, S. Freguia, P. Aelterman, W. Verstraete, K. Rabaey, Microbial fuel cells: methodology and technology, Environ. Sci. Technol. 40 (2006) 5181-5192.

[12] D. Pant, Van G. Bogaert, L. Diels, K. Vanbroekhoven, A review of the substrates used in microbial fuel cells (MFCs) for sustainable energy production, Bioresour. Technol. 101 (2010) 1533-1543.

[13] Y. Feng, X. Wang, B.E. Logan, H. Lee, Brewery wastewater treatment using air-cathode microbial fuel cells, Appl. Microbiol. Biotechnol. 78 (2008) 873-880.

[14] N. Lu, S. Zhou, L. Zhuang, J. Zhang, J. Ni, Electricity generation from starch processing wastewater using microbial fuel cell technology, Chem. Eng. J. 43 (3) (2009) 246-251.

[15] L. Huang, B.E. Logan, Electricity generation and treatment of paper recycling wastewater using a microbial fuel cell, Appl. Microbiol. Biotechnol. 80 (2008) 349-355.

[16] S.K. Dentel, B. Strogen, P. Chiu, Direct generation of electricity from sludges and other liquid wastes, Water Sci. Technol. 50 (9) (2004) 161-168.
[17] J. Jiang, Q. Zhao, J. Zhang, G. Zhang, D. Lee, Electricity generation from biotreatment of sewage sludge with microbial fuel cell, Bioresour. Technol. 100 (2009) 5808-5812.

[18] Z. Liu, X. Li, B. Jia, Y.Zheng, L. Fang, Q. Yang, D. Wang, G. Zeng, Production of electricity from surplus sludge using a single chamber floating-cathode microbial fuel cell, Water Sci. Technol. 60 (2009) 2399-2404.

[19] B. Xiao, F. Yang, J. Liu, Enhancing simultaneous electricity production and reduction of sewage sludge in two-chamber MFC by aerobic sludge digestion and sludge pretreatments, J. Hazard. Mater. 189 (2011) 444-449.

[20] G. Zhang, Q. Zhao, Y. Jiao, K. Wang, D. Lee, N. Ren, Efficient electricity generation from sewage sludge using biocathode microbial fuel cell, Water Res. 46 (2012) 43-52.

[21] J. Jiang, Q. Zhao, K. Wang, L. Wei, G. Zhang, J. Zhang, Effect of ultrasonic and alkaline pretreatment on sludge degradation and electricity generation by microbial fuel cell, Water Sci. Technol. 61 (11) (2010) 2915-2921.

[22] H. Wang, L. Liu, H. Hu, Electricity generation by microbial fuel cell using excess sludge with alkaline pretreatment as substrate, China Water Wastewater 28 (7) (2012) 5-8 (in Chinese).

[23] H. Yang, Z. Liu, X. Li, Q. Yang, L. Fang, H. Huang, G. Zeng, S. Li, Electricity generation of surplus sludge microbial fuel cells enhanced by additional enzyme, Environ. Sci. 33 (2012) 216-222 (in Chinese).

[24] T.H. Kim, Y.K. Nam, C. Park, M. Lee, Carbon source recovery from waste activated sludge by alkaline hydrolysis and gamma-ray irradiation for biological denitrification, Bioresour. Technol. 100 (2009) 5694-5699.

[25] D. Zhang, Y. Chen, Y. Zhao, Z. Ye, A new process for efficiently producing methane from waste activated sludge: alkaline pretreatment of sludge followed by treatment of fermentation liquid in an EGSB reactor, Environ. Sci. Technol. 45 (2011) 803-808.

[26] D.R. Lovley, E.J.P. Phillips, Novel mode of microbial energy metabolism: organic carbon coupled to dissimilatory reduction of iron or manganese, Appl. Environ. Microbiol. 54 (1988), 4172-1480.

[27] Q. Deng, X. Li, J. Zuo, A. Ling, B.E. Logan, Power generation using an activated carbon fiber felt cathode in an upflow microbial fuel cell, J. Power Sources 195 (2010) 1130-1135.

[28] K. Watanabe, Recent developments in microbial fuel cell technologies for sustainable bioenergy, J. Biosci. Bioeng. 106 (2008) 528-536.

[29] APHA, Standard Methods for the Examination of Water and Wastewater, 20th ed., APHA, Washington, DC, USA, 1998.

[30] O.H. Lowry, N.J. Rosebrough, A.L. Farr, R.J. Randall, Protein measurement with the Folin phenol reagent, J. Biol. Chem. 1993 (1951) 265-275.

[31] M. Dubois, K.A. Gilles, J.K. Hamilton, P.A. Rebers, F. Smith, Calorimetric method for determination of sugars and related substances, Anal. Chem. 28 (1956) 350-356.

[32] S. Moosvi, D. Madamwar, An integrated process for the treatment of CETP wastewater using coagulation, anaerobic and aerobic process, Bioresour. Technol. 98 (2007) 3384-3392.

[33] A. Moter, U.B. Göbel, Fluorescence in situ hybridization (FISH) for direct visualization of microorganisms, J. Microbiol. Methods 41 (2000) 85-112.

[34] C.M. Cordas, L.T. Guerra, C. Xavier, J.J.G. Moura, Electroactive biofilms of sulphate reducing bacteria, Electrochim. Acta 54 (1) (2008) 29-34.

[35] T. Li, Characteristics of membrane-aerated biofilms treating acetonitrile wastewater, Dissertation of Research Center for Eco-Environmental Sciences, Chinese Academy of Sciences, 2008 (in Chinese).

[36] X. Tang, K. Guo, H. Li, Z. Du, J. Tian, Microfiltration membrane performance in two-chamber microbial fuel cells, Biochem. Eng. J. 52 (2010) 194-198.

[37] Q. Wen, F. Kong, H. Zheng, D. Cao, Y. Ren, J. Yin, Electricity generation from synthetic penicillin wastewater in an air-cathode single chamber microbial fuel cell, Chem. Eng. J. 168 (2011) 572-576.

[38] J. Jiang, Q. Zhao, L. Wei, K. Wang, Extracellular biological organic matters in microbial fuel cell using sewage sludge as fuel, Water Res. 44 (2010) 2163-2170.

[39] C. Jiang, Y. Yuan, Z. Sun, S. Ye, H. Chen, Q. Pan, Effect of hydrostatic pressure and $\mathrm{pH}$ value on the three-dimensional fluorescence spectrum of tyrosine solution with various concentrations of copper ion, J. Lumin. 135 (2013) 42-46.

[40] A. Thygesen, F.W. Poulsen, B. Min, I. Angelidaki, A.B. Thomsen, The effect of different substrates and humic acid on power generation in microbial fuel cell operation, Bioresour. Technol. 100 (2009) 1186-1191.

[41] L. Huang, I. Angelidaki, Effect of humic acids on electricity generation integrated with xylose degradation in microbial fuel cells, Biotechnol. Bioeng. 100 (2008) 413-422.

[42] K.J. Chae, M.J. Choi, K.Y. Kim, F.F. Ajayi, W. Park, C.W. Kim, I.S. Kim, Methanogenesis control by employing various environmental stress conditions in two-chambered microbial fuel cells, Bioresour. Technol. 101 (2010) 5350-5357.

[43] H. Liu, S. Cheng, B.E. Logan, Production of electricity from acetate or butyrate using a single-chamber microbial fuel cell, Environ. Sci. Technol. 39 (2005) 658-662. 